Article

\title{
The Effect of Restoration Treatments on the Spatial Variability of Soil Processes under Longleaf Pine Trees
}

\author{
Martin Lavoie $^{1, *}$, Michelle C. Mack ${ }^{1}$, John K. Hiers ${ }^{2}$ and Scott Pokswinski ${ }^{3}$ \\ 1 Department of Biology, University of Florida, 220 Bartram Hall, Gainesville, FL 32611, USA; \\ E-Mail: mcmack@ufl.edu \\ 2 Eglin Air Force Base, Natural Resources Management, Jackson Guard, Niceville, FL 32578, USA; \\ E-Mail: john.hiers@eglin.af.mil \\ 3 Joseph W. Jones Ecological Research Center at Ichauway, Route 2, Box 2324, Newton, GA 39870, \\ USA; E-Mail: spokswin@jonesctr.org
}

* Author to whom correspondence should be addressed; E-Mail: martin21skifond@gmail.com; Tel.: +1-352-215-2249.

Received: 2 May 2012; in revised form: 10 July 2012 / Accepted: 25 July 2012 /

Published: 3 August 2012

\begin{abstract}
The objectives of this study were to (1) characterize tree-based spatial patterning of soil properties and understory vegetation in frequently burned ("reference state") and fire-suppressed longleaf pine forests; and (2) determine how restoration treatments affected patterning. To attain these objectives, we used an experimental manipulation of management types implemented 15 years ago in Florida. We randomly located six mature longleaf pine trees in one reference and four restoration treatments (i.e., burn, control, herbicide, and mechanical), for a total of 36 trees. In addition to the original treatments and as part of a monitoring program, all plots were subjected to several prescribed fires during these 15 years. Under each tree, we sampled mineral soil and understory vegetation at $1 \mathrm{~m}, 2 \mathrm{~m}$, $3 \mathrm{~m}$ and $4 \mathrm{~m}$ (vegetation only) away from the tree. At these sites, soil carbon and nitrogen were higher near the trunk while graminoids, forbs and saw palmetto covers showed an opposite trend. Our results confirmed that longleaf pine trees affect the spatial patterning of soil and understory vegetation, and this patterning was mostly limited to the restoration sites. We suggest frequent burning as a probable cause for a lack of spatial structure in the "reference state". We attribute the presence of spatial patterning in the restoration sites to accumulation of organic materials near the base of mature trees.
\end{abstract}


Keywords: ecosystem restoration; longleaf pine; prescribed burning; soil nutrients; spatial structure; understory vegetation

\section{Introduction}

Individual trees in woodland and forest ecosystem can create chemical and physical gradients that affect the spatial patterning of soil properties [1-3]. Trees can create gradients in soil moisture [4-6], temperature [7,8], texture [9], carbon (C) and nutrient accumulation and turnover [10-12], understory species composition through spatially distinct effects via litter accumulation $[1,12,13]$, stemflow and throughfall [14,15], light and precipitation interception [16-18] and root distribution [8,19].

Southeastern longleaf pine woodlands are one of the most endangered ecosystems in the United States due to decreased fire frequency and conversion of woodlands to agroforestry and agriculture [20,21]. These ecosystems were historically described as open, fire-maintained woodlands with a sparse but species-rich understory [21]. Frequently burned (i.e., fire frequency of 1-12 years) longleaf pine woodlands have very little organic matter on the ground, with the exception of a more substantial accumulation of litter and woody debris under the canopy of individual pines $[21,22]$. The most xeric sites - termed pine sandhills - tend to have very low organic matter accumulation [23] and open understory [24]. Modern fire suppression from forest management or agriculture, however, has led to hardwood encroachment, the development of a woody mid-story [25] and altered cover and composition of understory vegetation [23,26-28]. Without fire, litter from pines and hardwoods can accumulate as deep as $25 \mathrm{~cm}$, especially near the bases of large trees [22]. In savanna-type forests, levels of soil organic matter and nutrients are generally higher below the tree canopy [4,29]. In contrast, in other woodland ecosystems, the absence of fire tends to homogenize the distribution of soil organic matter and nutrients [30-32]. It is unknown whether longleaf pine woodlands exhibit strong tree-level spatial patterning of soil nutrients and understory vegetation when burned frequently or whether fire-suppression and woody encroachment alter spatial patterning.

Active management to restore the native community structure of longleaf pine woodlands has been underway in parts of the Southeast and often consists of hardwood removal by mechanical or chemical treatments and/or the re-introduction of frequent fire [33,34]. Re-introduction of fire to long-unburned stands (i.e., unburned for more than $\sim 10$ years) can reduce the hardwood component in the mid-story and facilitate the re-establishment of native forbs and graminoids in the understory [23,28,35,36]. Herbicide and mechanical treatments, by contrast, are more effective in removing the hardwood mid-story than in improving groundcover species richness $[23,28]$. Little is known, however, about the effects of any of these restoration treatments on the spatial patterning of soil biogeochemistry and understory vegetation.

In this study, we characterized the spatial variability of soil biogeochemistry and understory vegetation in relation to individual longleaf pine trees in reference stands and a 15 year-old experimental manipulation of restoration treatments on Eglin Air Force Base (EAFB), Florida, USA. In 1994, the Longleaf Pine Restoration Project (LPRP) was established in fire-suppressed longleaf pine sandhills on base lands to explore the effects of restoration treatments on community composition and soil 
processes [37]. Prior to the LPRP project, these fire-suppressed forest stands remained unburned for more than 20 years and were also subjected to some logging activities. Experimental treatments applied in 1994 included three hardwood reduction techniques (spring burning, herbicide application and mechanical (i.e., chainsaw felling and girdling)) and a control (continued fire-suppression). However, it should be noted that all plots (including controls) were subjected to several prescribed fires during the last 15 years as part of EAFB natural resources management. Reference sites (i.e., the target for restoration) where fires still occurred at a relatively high frequency (i.e., fire frequency of $<8$ years) were selected at the time of the initial experimental application and have been concurrently monitored. Fifteen years later, we revisited the LPRP and reference plots to determine whether the spatial patterning of soil processes and vegetation had been affected by the treatments. Our goals were to (1) characterize tree-based spatial patterning of soil characteristics and understory vegetation in the reference sites and restoration treatments; and (2) determine whether restoration treatments differed in their ability to restore spatial patterning to that seen in reference stands.

\section{Experimental Section}

\subsection{Study Sites}

Our study was conducted in longleaf pine forests at EAFB $\left(30^{\circ} 29^{\prime} 00^{\prime \prime} \mathrm{N} ; 86^{\circ} 31^{\prime} 52^{\prime \prime} \mathrm{W}\right)$, which is located on the panhandle of Florida, USA. This area was previously managed as the Choctawhatchee National Forest and was transferred to the Air Force in 1940. Soils of the study sites were typic Quartzipsamments of the Lakeland series with mean depth to water table of $200 \mathrm{~cm}$ [38]. The climate of the area is subtropical, with warm, humid summers and mild winters. Mean annual temperature is $19.8^{\circ} \mathrm{C}$, with a mean annual precipitation of $1580 \mathrm{~mm}$, most of which falls from June to September [38]. Study sites were 52-85 $\mathrm{m}$ above sea level, and all sites had the minimal topography typical of sandhills [39]. EAFB sandhills fall under Xeric Sand Barrens and Uplands of the Eastern Gulf Coastal Plain classification by Peet [24]. Vegetation was dominated by a longleaf pine overstory with a mid-story of various deciduous oaks, e.g., Quercus laevis Walter, Q. margaretta Ashe, Q. incana Bartram, Q. germinata Small.

\subsection{Sampling Design}

Five treatment blocks were established in 1994. Each block was composed of four $900 \mathrm{~m} \times 900 \mathrm{~m}$ plots with each plot representing one hardwood removal treatment (burn, mechanical, herbicide, and control). Six reference plots were also established in the site area. Reference plots were chosen based on "expert opinion" for the desired state for the natural ecosystem [24,40]. Each treatment was carried out only once but were under the EAFB natural resource management program, and all plots were subjected to a number of prescribed burns and wildfires between 1994 and 2009. During these 15 years, reference, burn, control, herbicide and mechanical plots were burned 9, 4, 3, 5 and 4 times respectively. All plots were burned between January and April 2009 prior to this study.

In August 2009, due to time and military mission constraints, we selected only one block of restoration treatments (consisting of four plots, one for each four restoration treatments) and one block for the reference (consisting of two plots), and we randomly located six mature longleaf trees in each plot (i.e., 6 plots $\times 6$ tree/plot). Under each tree, we removed the litter and organic layers and sampled 
mineral soil (0 to $20 \mathrm{~cm}$ ) at $1 \mathrm{~m}$ (near the trunk), $2 \mathrm{~m}$, and $3 \mathrm{~m}$ (outside the tree crown) away from the tree, at three directions $\left(0,120,240^{\circ}\right)$ and bulked samples by distance from the tree. At each sampling location, a 0 to $20 \mathrm{~cm}$ depth volumetric soil sample was taken with a $2.5 \mathrm{~cm}$ diameter soil core. For this study we concentrated on the $0-20 \mathrm{~cm}$ depth because it is the area with the highest density of fine roots $[41,42]$. Soil samples were kept on ice for transport back to University of Florida and kept at $4{ }^{\circ} \mathrm{C}$ for $<1$ week before processing.

In July 2011, we revisited the plots and the same 36 longleaf pine trees for a survey of the groundcover vegetation. Four $1 \mathrm{~m}$ line transects were placed perpendicular to each of the same three directions (i.e., $0^{\circ}, 120^{\circ}$, and $240^{\circ}$ ) from the trees at $1 \mathrm{~m}, 2 \mathrm{~m}, 3 \mathrm{~m}$ and $4 \mathrm{~m}$ for a total of 12 line transects per tree. Using the line-intercept method [43,44], percent cover was estimated as a proportion of the line covered by each vegetation category to the total length of the line $<1 \mathrm{~m}$ high. Vegetation was classified by eight categories: wiregrass (Aristida stricta Michx.), other graminoids, legumes, other forbs, saw palmetto (Serenoa repens W. Bartram), pines, other woody species, and moss. Graminoids were defined as any grass or sedge except wiregrass. Woody species were defined as any groundcover vegetation with a woody stem except saw palmetto or pines $(<1 \mathrm{~m}$ high). Cover classes were estimated for each of the eight vegetation categories crossing the plane of the line transect at $<1 \mathrm{~m}$ high: $0=0 \% ; 1-5=3 \% ; 6-10=8 \% ; 11-15=13 \% ; 16-25=21 \% ; 25-50=38 \% ; 51-75=68 \%$; 75-95 = 85\%; and 95-100 =98\%. Cover classes were assigned at the line transect level. To minimize error in cover estimation, a meter stick was used for the line transect so that the percent cover would equal the total $\mathrm{cm}$ of vegetation crossing the plane of the line transect. Due to the vertically stratified nature of the vegetation, it was possible to have total cover of all vegetation categories exceed $100 \%$.

\subsection{Soil Analysis}

Soils were homogenized by passing through a $<2 \mathrm{~mm}$ sieve and roots, twigs, and green vegetation were removed by hand. From each soil sample, a sub-sample was used to determine gravimetric moisture content, total soil $\mathrm{C}$ and $\mathrm{N}$, initial inorganic nitrogen $\left(\mathrm{NO}_{3}{ }^{-}-\mathrm{N}\right.$ and $\left.\mathrm{NH}_{4}{ }^{+}-\mathrm{N}\right)$, and initial basal respiration. Soil basal respiration and inorganic nitrogen $\left(\mathrm{NO}_{3}{ }^{-} \mathrm{N}\right.$ and $\left.\mathrm{NH}_{4}{ }^{+}-\mathrm{N}\right)$ were also measured after a 6-week aerobic laboratory incubation at field moisture and $25{ }^{\circ} \mathrm{C}$. Soil samples were adjusted with additional water during the incubation to maintain field moisture.

Total soil $\mathrm{C}$ and $\mathrm{N}$ were measured on subsamples of initial soil cores using a Costech ECS 4010 Elemental Analyzer (Costech Analytical Technologies, Inc., Valencia, CA, USA) and calculated on a dry soil mass (\%) and volume basis (e.g., $\mathrm{g} \mathrm{m}^{-2}$ ).

To determine basal respiration, we placed one specimen cup filled with approx. $30 \mathrm{~g}$ fresh weight soil into one $1 \mathrm{~L}$ Mason jar. We measured $\mathrm{CO}_{2}$ production from the samples by sealing the Mason jars and measuring $\mathrm{CO}_{2}$ accumulation in the headspace over a $96-\mathrm{h}$ period. Air samples $(10 \mathrm{~mL})$ were taken from the jar headspace at time 0 and at $96 \mathrm{~h}$ by syringe through a septum in the Mason jar lid, and injected into a Li-Cor $6252 \mathrm{CO}_{2}$ analyzer fitted with a calibrated injection port (Li-Cor, Nebraska, USA). Carbon flux rate was determined at the beginning of the incubation, after one week and after six weeks. Carbon dioxide production was expressed as $\mu \mathrm{g} \mathrm{C} \mathrm{gdw}{ }^{-1} \mathrm{~h}^{-1}$.

To determine $\mathrm{N}$ mineralization, soil samples were analyzed for initial and final pools of inorganic $\mathrm{N}$ $\left(\mathrm{NO}_{3}{ }^{-}-\mathrm{N}\right.$ and $\left.\mathrm{NH}_{4}{ }^{+}-\mathrm{N}\right)$ by extracting approximately $10 \mathrm{~g}$ of field moist soil with $50 \mathrm{~mL}$ of $2.0 \mathrm{M} \mathrm{KCL}$ [45]. 
The solutions were shaken for $1 \mathrm{~h}$ and left to sit in an air-conditioned room (approx. $23{ }^{\circ} \mathrm{C}$ ) for $18-24 \mathrm{~h}$ and then filtered using a Whatman (GF/A) filter under vacuum. Ammonium and $\mathrm{NO}_{3}{ }^{-}$concentrations in extracts were determined colorimetrically using an Astoria-Pacific colorimetric autoanalyzer (Astoria, Oregon, USA). Net rates of nitrification and $\mathrm{N}$ mineralization for the incubation period (i.e., six weeks) were calculated from the differences in initial and final inorganic $\mathrm{N}$ pools divided by the incubation time. All initial $\mathrm{N}$ pools and $\mathrm{N}$ rates were calculated on a dry soil mass basis (e.g., $\mu \mathrm{g} \mathrm{N} \mathrm{gdw}^{-1}$ ) and volume basis (e.g., $\mathrm{g} \mathrm{N} \mathrm{m}^{-2}$ ).

\subsection{Statistical Analysis}

To determine linearity between soil and vegetation characteristics and distance, we first fit regression lines separately for each treatment. To compare the regression lines, we used ANCOVA, with treatment as the categorical variable and distance as the continuous variable [46-48]. If an ANCOVA has a significant interaction between treatment and distance, it will indicate that the slope (i.e., distance) of the soil or vegetation variable analyzed differs for different treatments. Multiple comparisons of means were also performed with the Tukey's HSD post hoc test (see Table S1). All results are reported as significant when $p<0.05$. All statistical analyses were computed using R 2.14.2 [49,50].

\section{Results}

\subsection{Soil Nutrients}

In the herbicide plot, soil bulk density was positively related to distance (Table 1; Figure 1; Table S2). In contrast, our results show that $\mathrm{C}$ and $\mathrm{N}$ concentrations were negatively related to distance from the tree. These relationships were linear (i.e., nonzero slope) and similar (i.e., same slope) in the burn, control, herbicide and mechanical plots. In the burn and mechanical plots, soil $\mathrm{C}$ and $\mathrm{N}$ pools decreased with distance from the tree, while the $\mathrm{CN}$ ratio showed the same trend for the control plot only. These spatial patterns were, however, generally weak as distance never accounted for more than $25 \%$ of the variation. Additionally, $\mathrm{C}$ and $\mathrm{N}$ concentrations and pools were consistently lower in the reference than in the herbicide plot while soil bulk density showed greater values in the reference compare to the burn plot (Table S1).

Table 1. Summary analysis of covariance (ANCOVA) for the effect of restoration treatments $(\mathrm{df}=4)$ and distance $(\mathrm{df}=1)$ from the trunk and interaction $(\mathrm{df}=4)$ between treatment and distance on soil and vegetation characteristics for 36 longleaf pine (Pinus palustris) trees in longleaf pine forests at Eglin Air Force Base (EAFB), Florida.

\begin{tabular}{cccccccc}
\hline \multirow{2}{*}{ Responses variables } & \multicolumn{2}{c}{ Distance } & \multicolumn{2}{c}{ Treatment } & \multicolumn{3}{c}{$\mathbf{D} \times \mathbf{T}$} \\
\cline { 3 - 8 } & & $F$-value & $p$-value & $F$-value & $p$-value & $F$-value & $p$-value \\
\hline \multirow{4}{*}{ Soil } & Bulk Density $\left(\mathrm{g} \mathrm{cm}^{-3}\right)$ & 5.7 & 0.019 & 2.7 & 0.034 & 1.2 & 0.285 \\
characteristics & Moisture Content (\%) & 0.8 & 0.387 & 1.1 & 0.379 & 0.1 & 0.988 \\
& $\mathrm{C} \mathrm{( \% )}$ & 22.8 & $<0.001$ & 4.9 & 0.001 & 0.9 & 0.492 \\
& $\mathrm{~N} \mathrm{( \% )}$ & 16.4 & $<0.001$ & 9.2 & $<0.001$ & 0.6 & 0.692 \\
& $\mathrm{CN} \mathrm{ratio}$ & 5.2 & 0.0244 & 3.3 & 0.014 & 0.8 & 0.545 \\
& $\mathrm{C} \mathrm{pool}\left(\mathrm{g} \mathrm{m}^{-2}\right)$ & 12.4 & $<0.001$ & 3.9 & 0.005 & 0.8 & 0.538 \\
\hline
\end{tabular}


Table 1. Cont.

\begin{tabular}{|c|c|c|c|c|c|c|c|}
\hline & \multirow{2}{*}{ Responses variables } & \multicolumn{2}{|c|}{ Distance } & \multicolumn{2}{|c|}{ Treatment } & \multicolumn{2}{|c|}{$\mathbf{D} \times \mathbf{T}$} \\
\hline & & $F$-value & $p$-value & $F$-value & $p$-value & $F$-value & $p$-value \\
\hline \multirow{11}{*}{$\begin{array}{c}\text { Soil } \\
\text { characteristics }\end{array}$} & $\mathrm{N}$ pool $\left(\mathrm{g} \mathrm{m}^{-2}\right)$ & 5.9 & 0.017 & 6.4 & $<0.001$ & 0.8 & 0.571 \\
\hline & $\mathrm{NH}_{4}\left(\mathrm{~g} \mathrm{~N} \mathrm{gdw}^{-1}\right)$ & 0.4 & 0.562 & 1.2 & 0.324 & 2.0 & 0.105 \\
\hline & $\mathrm{NO}_{3}\left(\mathrm{~g} \mathrm{~N} \mathrm{gdw}^{-1}\right)$ & 0.5 & 0.463 & 3.0 & 0.022 & 0.7 & 0.571 \\
\hline & $\mathrm{NH}_{4}\left(\mathrm{~g} \mathrm{~m}^{-2}\right)$ & 0.1 & 0.906 & 1.0 & 0.425 & 2.4 & 0.059 \\
\hline & $\mathrm{NO}_{3}\left(\mathrm{~g} \mathrm{~m}^{-2}\right)$ & 1.9 & 0.172 & 2.4 & 0.054 & 0.7 & 0.572 \\
\hline & Nitrification $\left(\mathrm{g} \mathrm{N} \mathrm{gdw}^{-1} \mathrm{~d}^{-1}\right)$ & 0.1 & 0.719 & 2.6 & 0.041 & 4.3 & 0.003 \\
\hline & Mineralization $\left(\mathrm{g} \mathrm{N} \mathrm{gdw}^{-1} \mathrm{~d}^{-1}\right)$ & 0.1 & 0.858 & 2.1 & 0.087 & 1.1 & 0.356 \\
\hline & Nitrification $\left(\mathrm{g} \mathrm{N} \mathrm{m}^{-2} \mathrm{~d}^{-1}\right)$ & 0.1 & 0.834 & 2.6 & 0.038 & 4.1 & 0.004 \\
\hline & Mineralization $\left(\mathrm{g} \mathrm{N} \mathrm{m}^{-2} \mathrm{~d}^{-1}\right)$ & 0.0 & 0.959 & 2.1 & 0.098 & 1.1 & 0.356 \\
\hline & 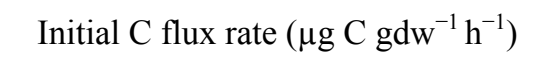 & 0.8 & 0.361 & 0.6 & 0.641 & 0.3 & 0.897 \\
\hline & 6-week C flux rate $\left(\mu \mathrm{g} \mathrm{C} \mathrm{gdw}^{-1} \mathrm{~h}^{-1}\right)$ & 0.9 & 0.352 & 1.1 & 0.353 & 1.3 & 0.268 \\
\hline \multirow{4}{*}{$\begin{array}{c}\text { Plant } \\
\text { functional } \\
\text { groups }\end{array}$} & Graminoids (\%) & 3.5 & 0.062 & 1.0 & 0.417 & 0.7 & 0.561 \\
\hline & Forbs $(\%)$ & 4.5 & 0.035 & 5.5 & $<0.001$ & 0.7 & 0.571 \\
\hline & Woody species (\%) & 3.7 & 0.057 & 8.0 & $<0.001$ & 2.4 & 0.054 \\
\hline & Saw palmetto (\%) & 4.7 & 0.003 & 5.5 & $<0.001$ & 0.9 & 0.468 \\
\hline
\end{tabular}

Figure 1. Relationships between soil properties and distance from the trunk of longleaf pine (Pinus palustris) trees $(\mathrm{n}=36)$ at Eglin Air Force Base (EAFB), Florida. Please note that jitter points were used to ovoid overplotting. Carbon and nitrogen are presented on a dry soil mass basis (i.e., $\mathrm{g} \mathrm{g}^{-1}$ ) and volume basis (i.e., $\mathrm{g} \mathrm{m}^{-2}$ ).

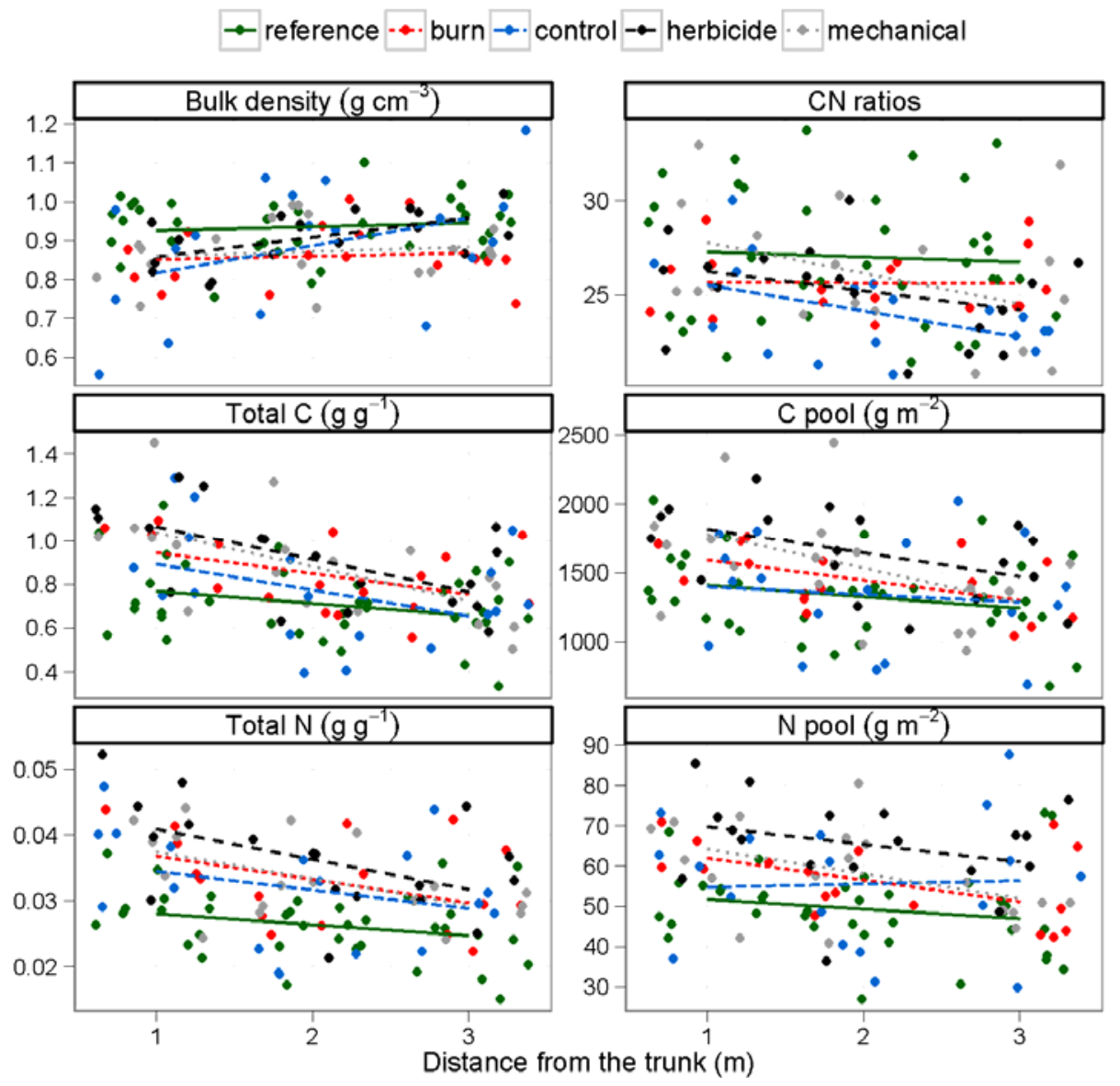




\subsection{Nitrogen and Carbon Mineralization Rates}

In the case of nitrification rates (mass and volume basis), the interaction between distance and treatment was significant, with a greater increase of the slope in the control plot (Table 1; Figure 2). On the other hand, we found no difference of spatial pattern or difference between treatments for inorganic N (Table 1; Figure 2; Tables S1 and S2). Additionally, we did not detect distance or treatment effects for $\mathrm{C}$ flux rates (data not shown).

Figure 2. Relationships between inorganic nitrogen and distance from the trunk of longleaf pine (Pinus palustris) trees $(\mathrm{n}=36)$ at EAFB, Florida. Please note that jitter points were used to ovoid overplotting. Values are presented on a dry soil mass basis (i.e., $\mathrm{g} \mathrm{g}^{-1}$ ) and volume basis (i.e., $\mathrm{g} \mathrm{m}^{-2}$ ).

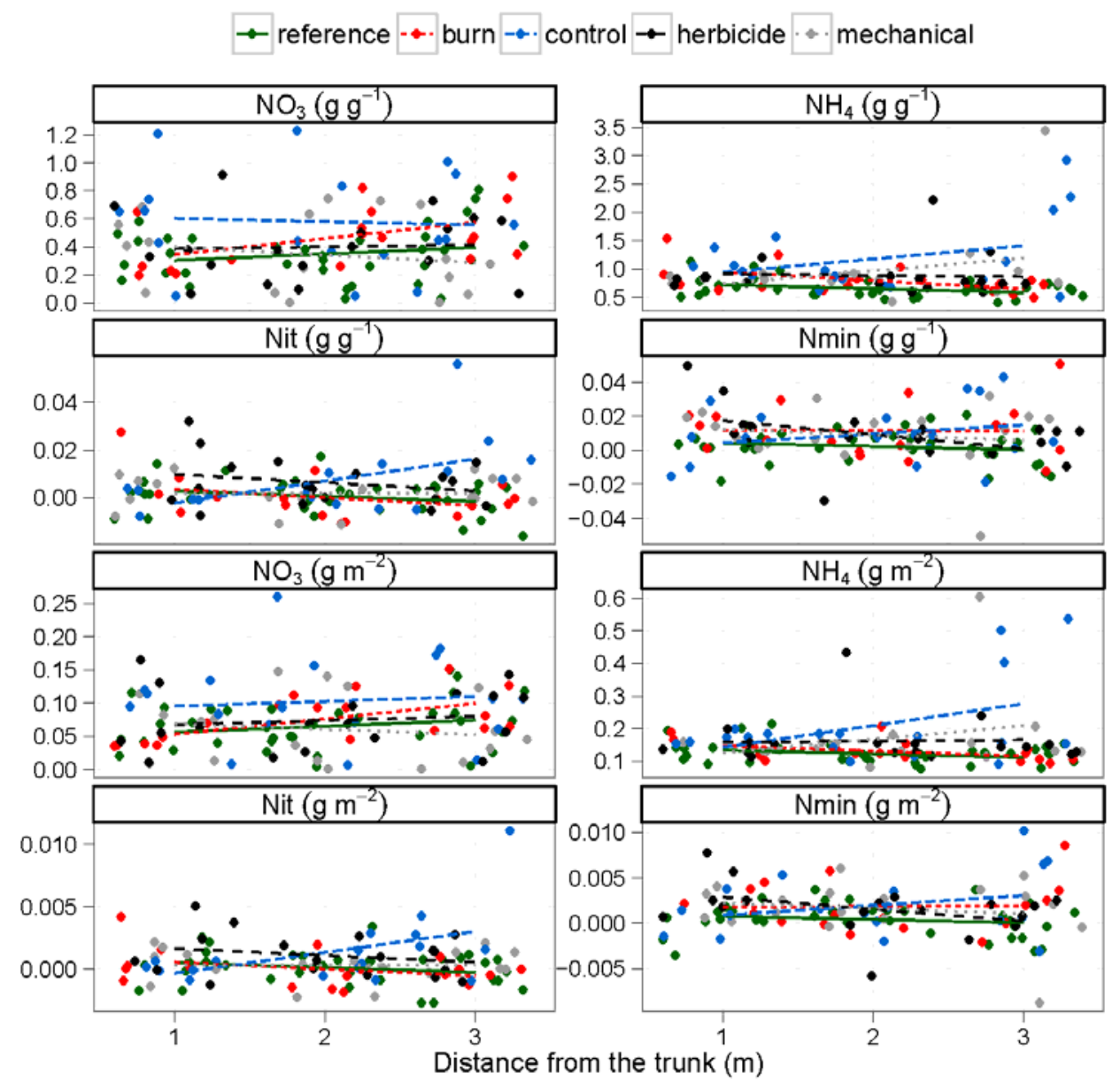

\subsection{Understory Vegetation}

We observed a linear relationship between plant functional group and distance from the trunk in reference and restoration plots (Table 1; Figure 3; Table S2). Graminoids, forbs and saw palmetto all increased with distance from the trunk but only in the reference, herbicide and reference plots respectively. Additionally, woody species cover showed a different spatial pattern in the control and reference plots, with a steeper rate of decrease with distance from the trunk (Figure 3). Finally, forbs 
cover was lower in the reference than the burn plot; woody species almost absent in the herbicide plot; and saw palmetto cover reaching 5\% only in the herbicide plot (see Table S1).

Figure 3. Relationships between understory vegetation covers (\%) and distance from the trunk of longleaf pine (Pinus palustris) trees $(\mathrm{n}=36)$ at EAFB, Florida. Please note that jitter points were used to ovoid overplotting.

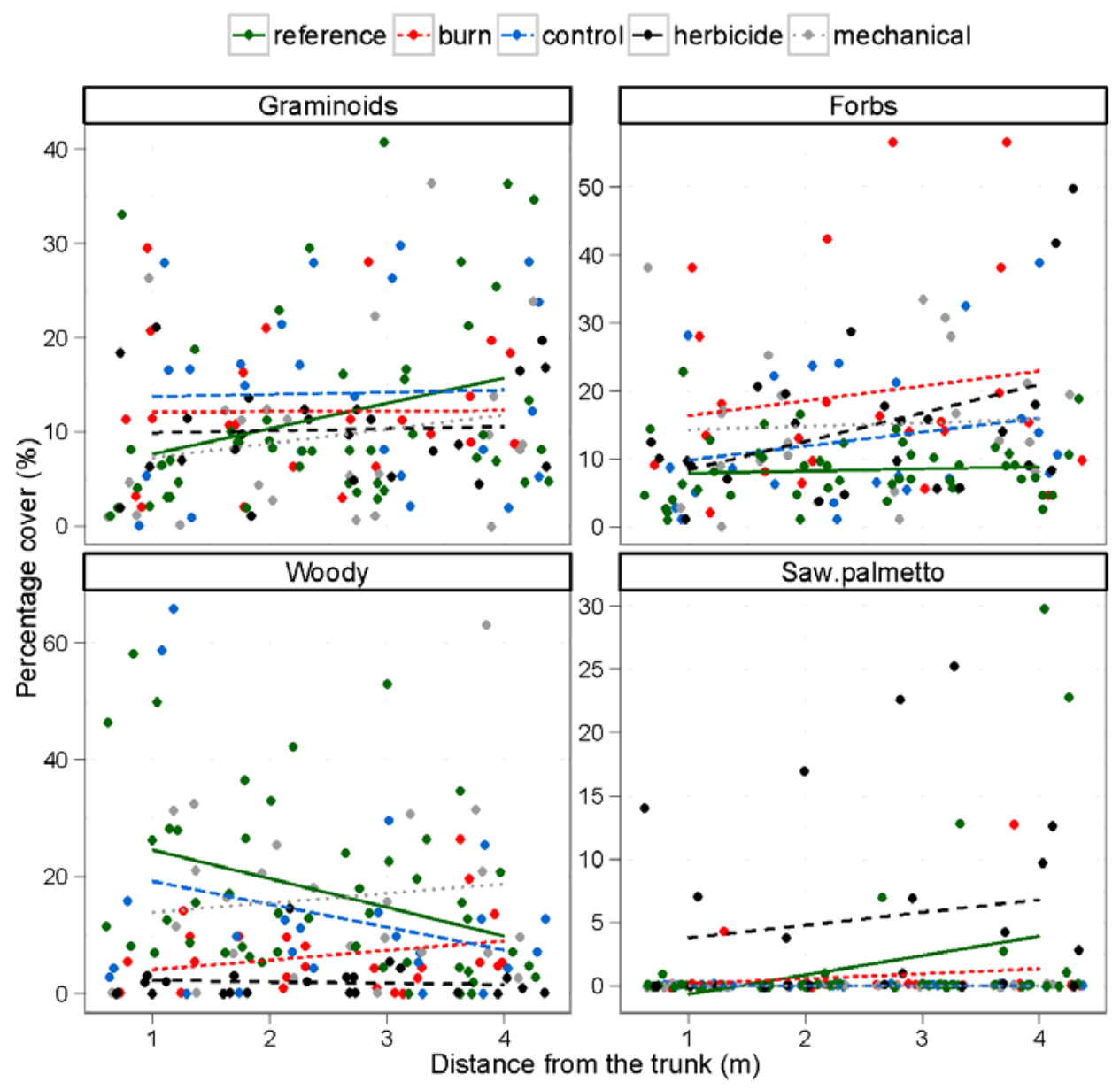

\section{Discussion}

In this study, we found evidence of spatial patterning associated with individual longleaf pine trees in the soils and vegetation of xeric pine sandhills, but this patterning was mostly limited to the restoration sites. Overall, total surface soil $\mathrm{C}, \mathrm{N}$, and $\mathrm{CN}$ ratio all decreased with distance from the tree, while soil bulk density increased. Graminoids, forbs, and saw palmetto also showed a distinctive spatial pattern, with covers increasing with distance from the tree. These effects were primarily driven by the reference and herbicide plots. In the reference and control plots, only woody understory cover showed significant spatial patterning, with more cover closer to the trees (i.e., decreasing slope).

Mean soil characteristics also differed between the reference and restored sites. For instance, soil C and $\mathrm{N}$ was consistently lower in the reference plots. One factor that may contribute to the lack of spatial structure and lower soil $\mathrm{C}$ and $\mathrm{N}$ concentrations in the reference treatment may be more frequent burning. The reference treatment was subjected to nine burns since the initiation of the LPRP project in 1994 (1994-2009), plus three additional fires prior to this project (1971-1994). In contrast, 
only four burns have been recorded in the restoration treatments over this time period, all occurring after 1994. In the absence of fire (or longer fire interval), pine litter and woody debris accumulation, in addition to hardwood establishment, may have led to the development of spatial gradients through higher inputs of organic matter near trees. Reintroduction of fire at a frequency of once every 4 years was apparently not enough to return soil $\mathrm{N}$ levels to historic conditions (i.e., $0.018 \%-0.027 \%$ ) [37].

\subsection{Soil Gradient}

Our results suggest that longleaf pine trees play a role in the spatial patterning of soil $\mathrm{C}$ and $\mathrm{N}$ concentrations, at least where long-term fire frequency is low. In the experimental plots, $\mathrm{C}$ and $\mathrm{N}$ concentrations were higher near the trunk where litter accumulation and forest floor depth are generally greater $[19,51,52]$. Indeed, Varner et al. [22] reported that without fire, litter from pines and hardwoods could accumulate as deep as $25 \mathrm{~cm}$ near the trunk of large trees. Burning of accumulated organic materials results in losses of $\mathrm{C}$ and $\mathrm{N}$ via volatilization, but also as an input, through ash, of soil $\mathrm{C}$ and $\mathrm{N}$ via leaching into the mineral soil [53].

Surprisingly, we found no evidence of this spatial structure in the reference plots. We suspect that the higher number of fires (i.e., fire frequency of $\sim 3$ years over the last 38 years) that occurred during several years prevented these accumulations of organic matter near the trunks. In addition, it may be that reference and restoration plots had pre-existing differences that were independent of fire history. We concentrated this study on one "reference state" and therefore we cannot generalize this conclusion to all "reference states". It may be that reference and restoration plots cover different ranges in state variation. For EAFB only, Rodgers and Provencher [54] described at least two distinct sandhill associations: burned-wiregrass (this study) and burned-bluestem. Peet [24] described additional longleaf pine associations, largely determined by edaphic variation and soil disturbance histories. Although soil texture did not differ between the reference and restoration plots [54], it may be that fine scale heterogeneity in other, unmeasured soil characteristics differed between these areas. In addition to soil characteristics, tree density and basal area may also vary among these "reference states" and may vary between our reference and restoration treatments, and this variation could be linked to recent history. It may also be that spatial structure in "reference states" with more savanna characteristics, such as low tree density and low canopy cover, differs from those with more similarities to woodlands (higher tree density, higher canopy cover).

Similarly, we found no clear evidence of spatial patterns of extractable inorganic N. The only exception was high nitrification rates in inter-canopy gaps, which only occurred in the control treatment that was burned only three times in 38 years (i.e., fire frequency of $\sim 12$ years). Higher net nitrification rates may indicate nitrogen available in excess of microbial demand and may reflect higher quality organic matter inputs from hardwoods [55].

\subsection{Vegetation Gradients}

In addition to affecting spatial patterns of soil nutrients, pine trees also had a small effect on the spatial patterning of understory vegetation. The effect varied but when the analysis was divided by functional groups, we detected an effect for graminoids and saw palmetto that was driven by the reference plots' trend towards increasing cover with distance from trees. For forbs, this same effect 
was also present but only in the herbicide treatment. These results may be attributed to better habitat conditions such as understory light availability following fuel and hardwood midstory reduction [56] or may reflect differences in available soil resources.

In contrast to the three other functional groups, the woody plants showed a different spatial structure, particularly for the reference and control plots. Surprisingly, woody cover was greater near the trees. Although, it remains unclear why repeated fires did not create a similar spatial structure for these plants.

\section{Conclusions}

Our study showed that longleaf pine trees did have an affect on the spatial patterning of soil and understory vegetation, but were most pronounced in the restoration sites. This result could be explained by frequent burning in the "reference state", and pre-existing differences between the reference and restorations sites. In addition, it is also possible that other longleaf pine stands with different disturbances histories or site characteristics (e.g., tree density, canopy cover) will express a different spatial structure of soil and understory vegetation.

\section{Acknowledgments}

The authors are thankful to Amanda Steen from the Joseph W. Jones Ecological Center and Brett Williams from Jackson Guard at EAFB for field assistance. We also thank Jenny Schafer, Jennie Demarco, Grace Crummer, and Julia Reiskind for laboratory assistance and Doria Gordon for valuable assistance. We are also grateful to four referees and Laura Schreeg for comments on earlier drafts of this manuscript. This research was supported by the Strategic Environmental Research and Development Program (Grant \# 09 SI01-001).

\section{Conflict of Interest}

The authors declare no conflict of interest.

\section{References}

1. Zinke, P.J. The pattern of influence of individual forest trees on soil properties. Ecology 1962, 43, 130-133.

2. Rhoades, C.C. Single-tree influence on soil properties in agroforestry: Lessons from natural forest and savanna ecosystems. Agrofor. Syst. 1997, 35, 71-94.

3. Saestre, P. Spatial patterns of ground vegetation, soil microbial biomass and activity in a mixed spruce-birch stand. Ecography 1999, 22, 183-192.

4. Ludvig, F.; de Kroon, H.; Berendse, F.; Prins, H.H.T. The influence of savanna trees on nutrient, water and light availability and the understorey vegetation. Plant Ecol. 2004, 170, 93-105.

5. Godefroid, S.; Koedan, N. Tree-induced soil compaction in forest ecosystems: Myth or reality? Eur. J. For. Res. 2010, 129, 209-217.

6. Weber, P.; Bardgett, R.D. Influence of single trees on spatial and temporal patterns of belowground properties in native pine forest. Soil Biol. Biochem. 2011, 43, 1372-1378. 
7. Ko, L.J.; Reich, P.B. Oak tree effects on soil and herbaceous vegetation in savannas and pastures in Wisconsin. Am. Midl. Nat. 1993, 130, 31-42.

8. Tang, J.; Baldocchi, D.D. Spatial-temporal variation in soil respiration in an oak-grass savanna ecosystem in California and its partitioning into autotrophic and heterotrophic components. Biogeochemistry 2005, 73, 183-207.

9. Mlambo, D.; Nyathi, P.; Mapaure, I. Influence of Colophospermum mopane on surface soil properties and understorey vegetation in a southern African savanna. For. Ecol. Manag. 2005, 212, 394-404.

10. Weltzin, J.F.; Coughenour, M.B. Savanna tree influence on understory vegetation and soil nutrients in northewestern Kenya. J. Veg. Sci. 1990, 1, 325-332.

11. Amiotti, N.M.; Zalba, P.; Sanchez, L.F.; Peinemann, N. The impact of single trees on properties of loess-derived grassland soils in Argentina. Ecology 2000, 81, 3283-3290.

12. Penne, C.; Ahrends, B.; Deurer, M.; Bottcher, J. The impact of the canopy structure on the spatial variability in forest floor carbon stocks. Geoderma 2010, 158, 282-297.

13. Lodhi, M.A.K. The influence and comparison of individual forest trees on soil properties and possible inhibition of nitrification due to intact vegetation. Am. J. Bot. 1977, 64, 260-264.

14. Ford, E.D.; Deans, J.D. The effects of canopy structure on stemflow, throughfall and interception loss in a young Sitka spruce plantation. J. Appl. For. 1978, 15, 905-917.

15. Seiler, J.; Matzner, E. Spatial variability of throughfall chemistry and selected soil properties as influenced by stem distance in a mature Norway spruce (Picea abies, Karst.) stand. Plant Soil 1995, 176, 139-147.

16. Battaglia, M.A.; Mou, P.; Palik, B.; Mitchell, R.J. The effect of spatially variable overstory on the understory light environment of an open-canopied longleaf pine forest. Can. J. Forest Res. 2002, 32, 1984-1991.

17. Palik, B.; Mitchell, R.J.; Pecot, S.; Battaglia, M.; Pu, M. Spatial distribution of overstory retention influences resources and growth of longleaf pine seedlings. Ecol. Appl. 2003, 13, 674-686.

18. Pecot, S.D.; Horsley, S.B.; Battaglia, M.A.; Mitchell, R.J. The influence of canopy, sky condition, and soilar angle on light quality in a longleaf pine woodland. Can. J. For. Res. 2005, 35, 1356-1366.

19. Brockway, D.G; Outcalt, K.W. Gap-phase regeneration in longleaf pine wiregrass ecosystems. For. Ecol. Manag. 1998, 106, 125-139.

20. Noss, R.F.; LaRoe, E.T.; Scott, J.M. Endangered Ecosystems of the United States: A Preliminary Assessment of Loss and Degradation; Biological Report 28; United States Department of Interiors: Washington, DC, USA, 1995.

21. Frost, C.C. History and future of the longleaf pine ecosystem. In The Longleaf Pine Ecosystem: Ecology, Silviculture, and Restoration; Jose, J., Jokela, E.J., Miller, D.L., Eds.; Springer: Berlin, Germany, 2006; pp. 9-48.

22. Varner, J.M., III.; Gordon, D.R.; Putz, F.E.; Hiers, J.K. Restoring fire to long-unburned Pinus palustris ecosystems: Novel fire effects and consequences for long-unburned ecosystems. Restor. Ecol. 2005, 13, 536-544.

23. Provencher, L.; Herring, B.J.; Gordon, D.R.; Rodgers, H.L.; Galley, K.E.M.; Tanner, G.W.; Hardesty, J.L.; Brennan, L.A. Effects of hardwood reduction techniques on longleaf pine sandhill vegetation in northwest Florida. Restor. Ecol. 2001, 9, 13-27. 
24. Peet, R.K. Ecological classification of longleaf pine woodlands. In The Longleaf Pine Ecosystem: Ecology, Silviculture, and Restoration; Jose, J., Jokela, E.J., Miller, D.L., Eds.; Springer: Berlin, Germany, 2006; pp. 51-93.

25. Moser, W.K.; Wade, D.D. Fire exclusion as a disturbance in the temperate forests of the USA: Examples from longleaf pine forests. Scand. J. For. Res. 2005, 20, 17-26.

26. Brockway, D.G.; Outcalt, K.W.; Wilkins, R.N. Restoring longleaf pine wiregrass ecosystems: Plant cover, diversity and biomass following low-rate hexazinone application on Florida sandhills. For. Ecol. Manag. 1998, 103, 159-175.

27. McGuire, J.P.; Mitchell, R.J.; Moser, E.B.; Pecot, S.D.; Gjerstad, D.H.; Hedman, C.W. Gaps in a gappy forest: Plant resources response to tree removal in longleaf pine savannas. Can. J. For. Res. 2001, 31, 765-778.

28. Provencher, L.; Herring, B.J.; Gordon, D.R.; Rodgers, H.L.; Tanner, G.W.; Hardesty, J.L.; Brennan, L.A.; Litt, A.R. Longleaf pine and oak responses to hardwood reduction techniques in fire-suppressed sandhills in northwest Florida. For. Ecol. Manag. 2001, 148, 63-77.

29. Brudvig, L.A.; Asbjornsen, H. The removal of woody encroachment restores biophysical gradients in Midwestern oak savannas. J. Appl. Ecol. 2009, 46, 231-240.

30. Blair, B.C. Fire effects on the spatial patterns of soil resources in a Nicaraguan wet tropical forest. J. Trop. Ecol. 2005, 21, 435-444.

31. Rodriguez, A.; Duran, J.; Fernandez-Palacios, J.M.; Gallardo, A. Spatial variability of soil properties under Pinus canariensis canopy in two contrasting soil textures. Plant Soil 2009, 322, 139-150.

32. Lavoie, M.; Mack, M.C. Spatial heterogeneity of understory vegetation and soil in an Alaskan upland boreal forest fire chronosequence. Biogeochemistry 2012, 107, 227-239.

33. Stanturf, J.A.; Wade, D.D.; Waldrop, T.A.; Kennard, D.K.; Achtemeir, G.L. Fire in Southern Forest Landscapes. In Southern Forest Resource Assessment: Summary Report; Wear, D.N., Greis, J.G., Eds.; General Technical Report SRS-54; US Department of Agriculture, Forest Service, Southern Research Station: Asheville, NC, USA, 2002; pp. 607-630.

34. Gagnon, J.L.; Jack, S.B. A Comparison of the Ecological Effects of Herbicide and Prescribed Fire in a Mature Longleaf Pine Forest: Response of Juvenile and Overstory Pine; General Technical Report SRS-71; US Department of Agriculture, Forest Service, Southeastern Forest Experiment Station: Asheville, NC, USA, 2004; pp. 304-308.

35. Menges, E.S.; Gordon, D.R. Should mechanical treatments and herbicides be used as fire surrogates to manage Florida's upland? A review. Florida Sci. 2010, 73, 147-174.

36. Stokes, T.A.; Samuelson, L.J.; Kush, J.S.; Farris, M.G.; Gilbert, J.C. Structure and diversity of longleaf pine (Pinus palustris Mill.) forest communities in the mountain longleaf national wildlife refuge, Northeastern Alabama. Nat. Area J. 2010, 30, 211-225.

37. Provencher, L.; Galley, K.E.M.; Herring, B.J.; Sheehan, J.; Gobris, N.M.; Gordon, D.R.; Tanner, G.W.; Hardesty, J.L.; Rodgers, H.L.; McAdoo, J.P.; Northrup, M.M.; McAdoo, S.J. Post-Treatment Analysis of Restoration Effects on Soils, Plants, Arthropods, and Birds in Sandhill Systems at Eglin Air Force Base, Florida; Annual Report to Natural Resources Division, Eglin Air Force Base, Niceville, FL; Public Lands Program, The Nature Conservancy: Gainesville, FL, USA, 1998. 
38. Overing, J.D.; Weeks, H.H.; Wilson, J.P.; Sullivan, J.; Ford, R.D. Soil Survey of Okaloosa Country, Florida; US Department of Agriculture, Natural Resource Conservation Service: Washington, DC, USA, 1995.

39. Myers, R.L. Schrub and high pine. In Ecosystem of Florida; Myers, R.L., Ewel, J., Eds; University of Florida Presses: Gainesville, FL, USA, 1990; pp. 174-193.

40. Landers, J.; Boyer, W.D. An Old-Growth Definition for Upland Longleaf and South Florida Slash Pine Forests, Woodlands, and Savannas; US Department of Agriculture, Forest Service, Southern Research Station: Asheville, NC, USA, 1999; pp. 1-15.

41. Jones, R.H.; Mitchell, R.J.; Stevens, G.N. Controls of fine root dynamics across a gradient of gap sizes in a pine woodland. Oecologia 2003, 134, 132-143.

42. Hendricks, J.J.; Hendricks, R.L.; Wilson, C.A.; Mitchell, R.J.; Pecot, S.D.; Guo, D. Assessing the patterns and controls of fine root dynamics: An empirical test and methodological review. J. Ecol. 2006, 94, 40-57.

43. Canfield, R.H. Application of the lime interception method in sampling range vegetation. J. For. 1941, 39, 388-394.

44. Bauer, H.L. The statistical analysis of chaparral and other plant communities by means of transect samples. Ecology 1943, 24, 45-60.

45. Keeney, D.R.; Nelson, D.W. Nitrogen-inorganic forms. In Methods of Soil Analysis Part 2-Chemical and Microbiological Properties, 2nd ed.; Page, A.L., Miller, R.H., Keeney, D.R., Eds.; Soil Science Society of America: Madison, WI, USA, 1982; pp. 643-698.

46. Amiotti, N.M.; Bravo, O.; Zalba, P.; Peinemann, N. Effect of landscape position on the acidification of loess-derived soils under Pinus radiata. Austral Ecol. 2007, 32, 534-540.

47. Zuur, A.; Ieno, E.N.; Walker, N.; Saveiliev, A.A.; Smith, G.M. Mixed Effects Models and Extensions in Ecology with R; Springer: New York, NY, USA, 2009.

48. Crawley, M.J. The R Book; John Wiley \& Sons Ltd.: Chichester, UK, 2007.

49. R Development Core Team. R: A Language and Environment for Statistical Computing; R Foundation for Statistical Computing: Vienna, Austria, 2012.

50. Pinheiro, J.; Bates, D.; DebRoy, S.; Sarkar, D. Nlme: Linear and Nonlinear Mixed Effects Models, version 3.1-104; R Development Core Team: Vienna, Austria, 2012.

51. Avery, C.R.; Cohen, S.; Parker, K.C.; Kush, J.S. Spatial pattern of longleaf pine (Pinus palustris) seedling establishment on the croatan national forest, North Carolina. J. North Carol. Acad. Sci. 2004, 120, 131-142.

52. Boring, L.R.; Hendricks, J.J.; Wilson, C.A.; Mitchell, R.J. Seasonal of burn and nutrient losses in a longleaf pine ecosystem. Int. J. Wildland Fire 2004, 13, 443-453.

53. Noble, M.M.; Dillon, W.; Mhila, M. Initial response of soil nutrient pools to prescribed burning and thinning in a managed forest ecosystems of northern Alabama. Soil Sci. Soc. Am. J. 2009, 73, 285-292.

54. Rodgers, H.L.; Provencher, L. Analysis of longleaf pine sandhill vegetation in northwestern Florida. Castanea 1999, 64, 138-162.

55. Wilson, C.A.; Mitchell, R.J.; Hendricks, J.J.; Boring, L.R. Patterns and control of ecosystem function in longleaf pine-wiregrass. II. Nitrogen dynamics. Can. J. For. Res. 1999, 29, 752-760. 
56. Platt, W.J.; Carr, S.M.; Reilly, M.; Fahr, J. Pine savanna overstorey influences on ground-cover biodiversity. Appl. Veg. Sci. 2006, 9, 37-50.

(C) 2012 by the authors; licensee MDPI, Basel, Switzerland. This article is an open access article distributed under the terms and conditions of the Creative Commons Attribution license (http://creativecommons.org/licenses/by/3.0/). 